\title{
Pituitary Adenylate Cyclase-Activating Polypeptide and Vasoactive Intestinal Peptide Inhibit Dendritic Growth in Cultured Sympathetic Neurons
}

\author{
Karen Drahushuk, ${ }^{1}$ Terry D. Connell, ${ }^{2}$ and Dennis Higgins ${ }^{1}$ \\ Departments of ${ }^{1}$ Pharmacology and Toxicology and ${ }^{2}$ Microbiology and the Witebsky Center for Microbial Pathogenesis \\ and Immunology, State University of New York at Buffalo, Buffalo, New York 14214
}

Pituitary adenylate cyclase-activating polypeptide (PACAP) and vasoactive intestinal peptide (VIP) are related neuropeptides that are released by the preganglionic sympathetic axons. These peptides have previously been implicated in the regulation of sympathetic neurotransmitter metabolism and cell survival in postganglionic sympathetic neurons. In this study we consider the possibility that PACAP and VIP also affect the morphological development of these neurons. Postganglionic rat sympathetic neurons formed extensive dendritic arbors after exposure to bone morphogenetic protein-7 (BMP-7) in vitro. PACAP and VIP reduced BMP-7-induced dendritic growth by $\sim 70-90 \%$, and this suppression was maintained for 3 weeks. However, neither PACAP nor VIP affected axonal growth or cell survival. The actions of PACAP and VIP appear to be mediated by $\mathrm{PAC}_{1}$ receptors because their effects were suppressed by an antagonist that binds to $\mathrm{PAC}_{1}$ and $\mathrm{VPAC}_{2}$ receptors (PACAP638 ), but not by an antagonist that binds to the $V_{P A C}$ and $\mathrm{VPAC}_{2}$ receptors. Moreover, exposure to PACAP and VIP caused phosphorylation and nuclear translocation of cAMP response element-binding protein, and agents that increase the intracellular concentration of cAMP mimicked the PACAPinduced inhibition of dendritic growth. These data suggest that peptides released by preganglionic nerves modulate dendritic growth in sympathetic neurons by a cAMP-dependent mechanism.

Key words: vasoactive intestinal peptide; pituitary adenylate cyclase activating polypeptide; BMP-7; CAMP; dendrite; sympathetic
Dendrites are the primary site of synaptic formation in the vertebrate nervous system; therefore, regulation of their growth is critical for the establishment of proper neural circuitry (Purves et al., 1988). One class of molecules that controls the growth of these processes is trophic factors, and their actions on sympathetic neurons have been extensively analyzed. Two different classes of growth factors, bone morphogenetic proteins (BMPs) and neurotrophins, stimulate dendritic growth in these neurons (Snider, 1988; Lein et al., 1995; Guo et al., 1998). In contrast, leukemia inhibitory factor (LIF) and other neuropoetic cytokines have a contravening action: they inhibit the initial growth of dendrites and also cause retraction of existing processes (Guo et al., 1997, 1999). In addition to growth factors, neurotransmitters have also been implicated in the control of dendritic growth (for review, see Spencer et al., 1998). The primary excitatory neurotransmitter in the CNS is glutamate, which has been found to modulate dendritic growth in hippocampal, retinal, cortical, and cerebellar neurons (May et al., 1995, 1998; Hasbani et al., 1998; Lima et al., 1998; Hirai and Launey, 2000; Wilson et al., 2000). However, little is known of the effects of neurotransmitters on dendritic growth in the PNS. Therefore, we have examined the effects of the interactions of trophic factors and neurotransmitters on the de-

Received Jan. 9, 2002; revised April 25, 2002; accepted May 7, 2002.

This work was funded by National Science Foundation Grant 01-21210 (D.H.) and The Mark Diamond Research Fund of the Graduate Student Association at the State University of New York at Buffalo (K.D.). We thank Vidya Chandersakaran, Craig Horbinski, and In-Jung Kim for their assistance with this study.

Correspondence should be addressed to K. Drahushuk, State University of New York at Buffalo, 102 Farber Hall, 3435 Main Street, Buffalo, NY 14214. E-mail: drahushu@buffalo.edu.

Copyright (ㄷ) 2002 Society for Neuroscience $\quad 0270-6474 / 02 / 226560-10 \$ 15.00 / 0$ velopment of the dendritic arbor in cultures of sympathetic neurons.

The preganglionic neurons that innervate the superior cervical ganglion (SCG) are cholinergic (Landis, 1994; Ip and Zigmond, 2000). In addition, most of the preganglionic fibers contain either pituitary adenylate cyclase-activating polypeptide (PACAP) or the related neuropeptide, vasoactive intestinal peptide (VIP) (Baldwin et al., 1991; Sasek et al., 1991; Beaudet et al., 1998). Previous studies by our laboratory indicate that neither cholinergic agonists nor antagonists affect dendritic growth in vitro (Guo et al., 1997). Therefore, we focused on the effects of the peptides secreted by the afferent axons. These peptides have been shown to affect synaptic transmission, neurotransmitter metabolism, differentiation, proliferation, and cell survival in sympathetic ganglia (May et al., 1995, 1998; Beaudet et al., 2000; DiCicco-Bloom et al., 2000; Nicot and DiCicco-Bloom, 2001); however, their affects on cell shape are unknown.

PACAP and VIP belong to the secretin family of peptides and signal via one of three postsynaptic receptors: $\mathrm{PAC}_{1}, \mathrm{VPAC}_{1}$, or $\mathrm{VPAC}_{2}$ (Baldwin et al., 1991; Beaudet et al., 1998; May et al., 1998). However, only the high-affinity PACAP receptor $\mathrm{PAC}_{1}$ has been identified in postganglionic sympathetic neurons (Nogi et al., 1997; Lu et al., 1998, DiCicco-Bloom et al., 2000). The PAC receptor has $\sim 3000$-fold lower affinity for VIP than for PACAP38 and PACAP27, the primary PACAP isoforms found in the SCG, and it can activate multiple signaling transduction systems, including the Gs $\alpha$ /adenylate cyclase signal transduction cascade (Pisegna and Wank, 1993; Spengler et al., 1993; Lu et al., 1998). We therefore examined the roles of VIP, PACAP38, PACAP27, and cyclic nucleotides in the regulation of dendritic morphology of sympathetic neurons. Our data indicate that VIP 

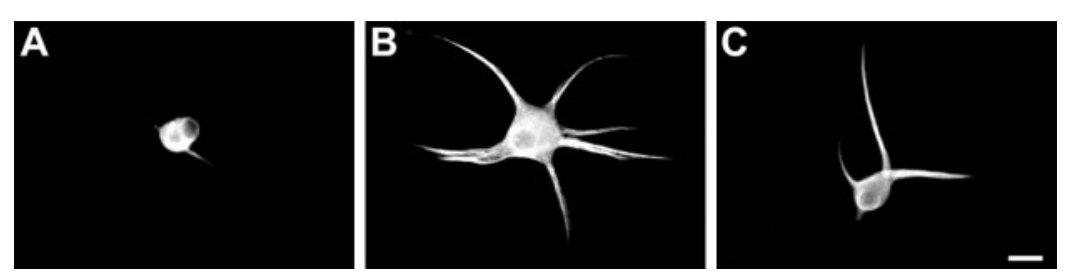

Figure 1. PACAP38 inhibits BMP-7-induced dendritic growth in cultured sympathetic neurons. Sympathetic neurons were immunostained with an antibody to MAP-2, a protein localized primarily to the somata and dendrites. Neurons grown under control conditions did not form dendrites $(A)$, whereas those exposed to BMP-7 $(50 \mathrm{ng} / \mathrm{ml})$ for $5 \mathrm{~d}$ typically extended six to seven dendrites per cell $(B)$. In contrast, neurons treated for $5 \mathrm{~d}$ with BMP-7 $(50 \mathrm{ng} / \mathrm{ml})$ in the presence of $1 \mu \mathrm{M}$ PACAP $(C)$ or $10 \mu \mathrm{M}$ VIP (data not shown) had an average of one to two dendrites per cell. Scale bar, $20 \mu \mathrm{m}$. and PACAP profoundly inhibit dendritic development in sympathetic neurons and that they act by increasing intracellular levels of cAMP. These effects could contribute to the refinement of developing neural circuitry and could also play a role in modulating neuronal shape after neural injury (Sun et al., 1994, 1996; Guo et al., 1997, 1999). Interactions between the PACAP/VIP and BMP-7 signaling pathways represent an activity-dependent method for regulating sympathetic dendritic growth.

\section{MATERIALS AND METHODS}

Tissue culture. Superior cervical ganglia were isolated from perinatal (embryonic day 21 to postnatal day 1) Holtzman rat pups (Harlan Sprague Dawley, Indianapolis, IN) according to the method of Higgins et al. (1991). Neurons were enzymatically and mechanically dissociated and plated onto $18 \mathrm{~mm}$ glass coverslips coated with poly-D-lysine $(100 \mu \mathrm{g} / \mathrm{ml})$. Cultures were plated and grown in a serum-free medium (Lein and Higgins, 1991), supplemented with $\beta$-NGF (100 ng/ml; Harlan Bioproducts for Science, Madison, WI), bovine serum albumin $(500 \mu \mathrm{g} / \mathrm{ml})$, bovine insulin $(10 \mu \mathrm{g} / \mathrm{ml})$, human transferrin $(10 \mu \mathrm{g} / \mathrm{ml})$, L-glutamine $(200 \mu \mathrm{g} / \mathrm{ml})$, and selenium $(5 \mathrm{ng} / \mathrm{ml})$. Cytosine- $\beta$-D-arabinof uranoside (1 $\mu \mathrm{M})$ was added to the culture medium $\sim 24 \mathrm{hr}$ after the initial plating for $48 \mathrm{hr}$ to eliminate non-neuronal cells. Virtually no non-neuronal cells $(<50$ cells per $18 \mathrm{~mm}$ coverslip) survive after anti-mitotic treatment in our cultures (Higgins et al., 1991). Cultures were allowed to recover from anti-mitotic treatment for $48 \mathrm{hr}$ before experimental treatments commenced; experimental agents were added every $2 \mathrm{~d}$. Experiments were usually repeated three or more times.

Morphological analyses. Cultures were fixed with $4 \%$ paraformaldehyde for $15 \mathrm{~min}$ and permeabilized for 4 min with $0.1 \%$ Triton X-100 in PBS. Cultures were immunostained with a monoclonal antibody to MAP-2, a protein found primarily in dendrites (SMI 52; Sternberger Monoclonals, Lutherville, MD; $2 \mu \mathrm{g} / \mathrm{ml}$ ), followed by detection with a rhodamine-labeled secondary antibody (Roche Diagnostics, Indianapolis, IN; $4 \mu \mathrm{g} / \mathrm{ml}$ ). Dendritic growth was also assessed using the fluorescent nucleic acid binding dye YOYO-1 iodide (491/509) (Molecular Probes, Eugene, OR; $16 \mathrm{ng} / \mathrm{ml}$ ). Nucleic acid binding dyes have been used by other laboratories to label dendrites (Knowles et al., 1996; Kiebler et al., 1999). Both the number of dendrites per cell $(n \geq 60$ per treatment) and total dendritic length ( $n \geq 30$ per treatment) were assessed. Dendritic length was measured using calibrated SPOT imaging software (Diagnostic Instruments, Sterling Heights, MI). Only neurons with somata separated from neighboring cell bodies by at least $150 \mu \mathrm{m}$ were counted, because differences in the proximity of neurons has been shown to result in morphological changes in the dendritic arbor (Bruckenstein et al., 1989). Statistical significance was assessed by ANOVA followed by Tukey's post hoc test. Data are expressed as mean \pm SEM.

Changes in cAMP response element-binding protein (CREB) phosphorylation and cellular localization were assessed after fixation and permeabilization (as described above) using a polyclonal antibody to phosphorylated CREB (Ser133, Cell Signaling Technology, Beverly, $\mathrm{MA} ; 50 \mathrm{ng} / \mathrm{ml}$ ) and a rhodamine-conjugated secondary antibody (rabbit IgG; Roche Molecular Biochemicals, Indianapolis, IN; $2 \mu \mathrm{g} / \mathrm{ml}$ ).

Western blotting. Proteins were extracted from cultures of sympathetic neurons grown on $35 \mathrm{~mm}$ dishes with $150 \mu \mathrm{l}$ of buffer containing SDS $(0.1 \%)$, EDTA (1 mM), Tris $\mathrm{HCl}$ (50 mu, pH 7.4), and $\beta$-mercaptoethanol $(2 \%)$. Protein concentrations were determined using Bradford dye reagent (Bio-Rad, Hercules, CA). SDS-PAGE (7\%) was performed according to the method of Laemmli (1970), followed by transfer to a nitrocellulose membrane (Bio-Rad). Membranes were initially treated with nonfat milk $(5 \%)$ in PBS and probed with a monoclo- nal antibody to tau (Tau1, $2.8 \mu \mathrm{g} / \mathrm{ml}$; Sigma-Aldrich, St. Louis, MO) or $\beta$-tubulin (1:100; generously provided by Dr. Robert Hard, State University of New York at Buffalo). Antibodies were diluted in BSA (5\%) in PBS. Bands were detected by chemiluminescence (SuperSignal Substrate, Pierce Chemical Co., Rockford, IL) after consecutive incubations with biotinylated anti-mouse IgG (Hyclone Laboratories, Logan, UT; $500 \mathrm{ng} / \mathrm{ml}$ ) and HRP-conjugated streptavidin (Amersham Biosciences, Piscataway, NJ; $1.4 \mu \mathrm{g} / \mathrm{ml}$ ).

Materials. Peptides were purchased from the following vendors: PACAP27, PACAP38; and PACAP6-38 from American Peptide Co. (Sunnyvale, CA); leu-enkephalin, VIP, and NPY from Bachem California (Torrance, CA.); SQ22536 from Calbiochem (San Diego, CA); U73122 from Biomol Research Laboratories (Plymouth Meeting, PA); and the growth hormone-releasing factor analog GRF (Ac-Tyr1,D-Phe2) (1-29) amide (GRF) from California Peptide Research (Napa, CA). Terry D. Connell (State University of New York at Buffalo) provided cholera toxin, enterotoxin LT-IIa, and their respective nontoxic B pentamers. BMP-7 was a generous gift from Curis, Inc. (Cambridge, MA).

\section{RESULTS}

\section{PACAP38 and VIP inhibit BMP-7-induced dendritic growth in cultured sympathetic neurons}

Cultures of sympathetic neurons were maintained in the absence of serum and treated with an anti-mitotic agent to eliminate non-neuronal cells. Experimental treatments began on the fifth day. Under these conditions, sympathetic neurons develop extensive axonal arbors (Lein et al., 1995), but they do not form dendrites (Fig. 1). Cells treated with BMP-7 started to extend dendrites within $24 \mathrm{hr}$ and developed an average of six to seven dendrites per cell by the seventh day of treatment (Fig. 1). Exposure to PACAP38 did not alter the morphological development of neurons in control media; however, it profoundly depressed the response to BMP-7. This inhibition was manifest as a decrease in both the number of primary dendrites per cell and the size of the dendritic arbor. In addition, there was a $\sim 50 \%$ decrease in the percentage of cells bearing dendrites (data not shown). The inhibitory effects of PACAP38 were apparent by the third day of treatment and persisted for at least $21 \mathrm{~d}$ (Fig. 2). The magnitude of the inhibition typically became greater with continued exposure to the peptide, increasing from 50 to $60 \%$ inhibition after $7 \mathrm{~d}$ to $\sim 90 \%$ inhibition after $21 \mathrm{~d}$.

Inhibition of BMP-7-induced dendritic growth was also observed with VIP, and the magnitude of the effect was comparable to that obtained with PACAP38 (Fig. 3). In contrast, neuropeptide $\mathrm{Y}$, leu-enkephalin, and substance $\mathrm{P}$ were inactive. Thus, peptides belonging to the PACAP/VIP family have the capacity to alter the morphological development of sympathetic neurons, whereas other peptides known to be present in sympathetic ganglia are inactive.

\section{PACAP38 does not affect survival or health of sympathetic neurons}

Inhibition of dendritic extension could reflect either the activation of specific intracellular signaling pathways or nonspecific cellular 


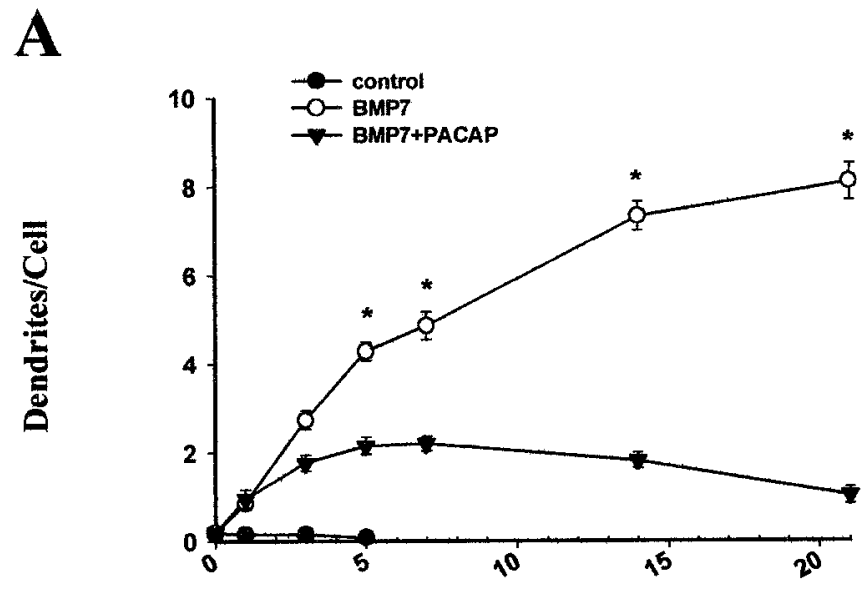

Days of Treatment

B

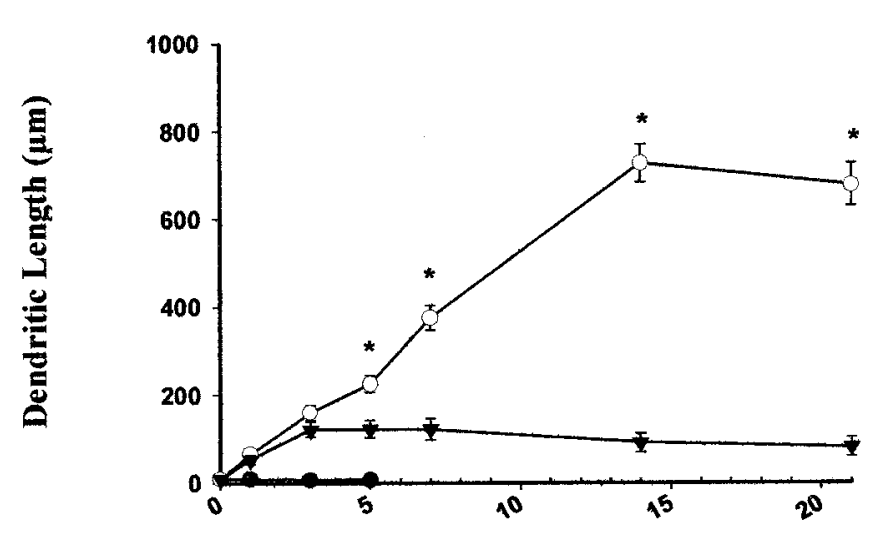

Days of Treatment

Figure 2. Time course of inhibition of dendritic growth by PACAP38. Cells were grown in control medium or treated with BMP-7 $(50 \mathrm{ng} / \mathrm{ml})$ in the presence or absence of PACAP38 $(1 \mu \mathrm{M})$, after which the number of dendrites per cell $(A)$ and total dendritic length $(B)$ were assessed by immunostaining with an antibody to MAP-2. ${ }^{*} p<0.05$ versus BMP-7.

toxicity (Isokawa and Mello, 1991; Pfau et al., 1995; Johnson and Bywood, 1998). Therefore, possible changes in cell survival or axonal growth after treatment by PACAP38 were examined. PACAP38 did not affect the number of viable cells (Fig. 4) or the appearance of the axonal network (Fig. 5). Total axonal development was also assessed by Western immunoblotting using an antibody specific for tau, a microtubule-associated protein predominantly localized to neural axons (Fig. 5) (Kosik and Caceres, 1991; Paglini et al., 2000). For this experiment, the high molecular weight tau isoform was examined because it is less susceptible to phosphorylation effects by protein kinase A (PKA), unlike the low molecular weight tau (Taleghany and Oblinger, 1992). Tau expression remained unaffected by treatment with BMP-7 in either the presence or absence of PACAP38 (Fig. 5). In addition, total cellular protein remained unchanged after each of these treatments (data not shown).

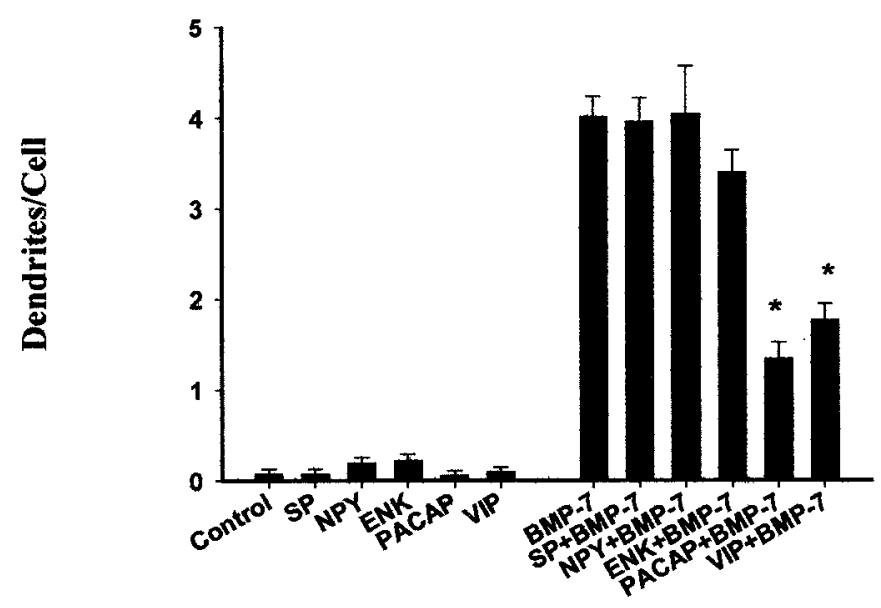

Figure 3. PACAP and VIP selectively inhibit BMP-7-induced dendritic growth. Beginning on the fifth day in vitro, sympathetic neurons were maintained in either control medium or medium with BMP-7 $(50 \mathrm{ng} / \mathrm{ml})$. At this time, neurons were also exposed to BMP-7 in the presence of one of the following: VIP, PACAP, neuropeptide Y (NPY), or substance $\mathrm{P}$ $(S P)$. All peptides were used at $10 \mu \mathrm{M}$, except for PACAP38, which was used at $1 \mu \mathrm{M}$ to prevent toxicity. Cellular morphology was assessed by MAP-2 immunostaining. * $p<0.05$ versus BMP-7.

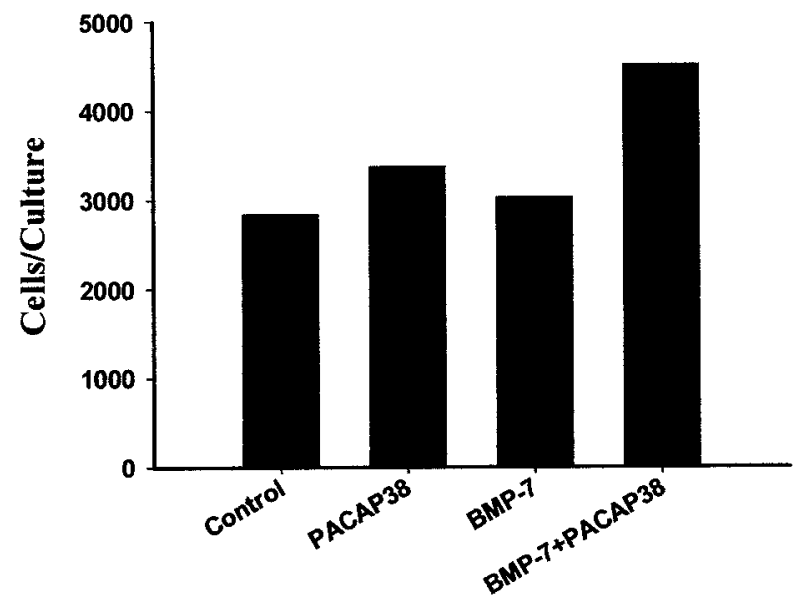

Figure 4. Effects of PACAP38 on survival of sympathetic neurons. A, Cultures were treated with BMP-7 $(50 \mathrm{ng} / \mathrm{ml})$ and PACAP38 $(1 \mu \mathrm{M})$, or both, and cell number was determined $5 \mathrm{~d}$ later. Differences between groups are not statistically significant by one-way ANOVA $(p>0.05)$.

\section{The $\mathrm{PAC}_{1}$ receptor mediates the inhibition of BMP-7-induced dendrite growth by PACAP27 and VIP}

Three receptors for PACAP38 and VIP have been identified. They include the $\mathrm{PAC}_{1}, \mathrm{VPAC}_{1}$, and $\mathrm{VPAC}_{2}$ receptors. The $\mathrm{PAC}_{1}$ receptor has a 3000 -fold greater affinity for PACAP38 and its related analog PACAP27 than for VIP (Lu et al., 1998). The $\mathrm{VPAC}_{1}$ and $\mathrm{VPAC}_{2}$ receptors, however, exhibit equivalent affinities for VIP, PACAP27, and PACAP38. Therefore, to identify the neuropeptide receptor subtype(s) mediating dendritic growth, we examined concentration-effect relationships for PACAP38, VIP, and PACAP27.

PACAP38, VIP, and PACAP27 inhibited initial dendritic outgrowth in a concentration-dependent manner, and the maximally effective concentration of each agent depressed it to a similar degree ( $\sim 60 \%$ inhibition). However, PACAP38 and PACAP27 were effective at concentrations as low as $10 \mathrm{pM}$ and had an $\mathrm{IC}_{50}$ of $\sim 1 \mathrm{~nm}$ (Fig. 6). In contrast, VIP was much less potent, with an 
A

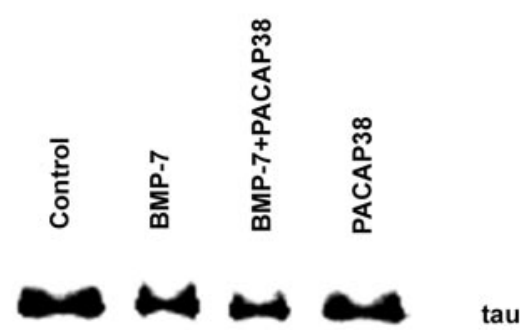

B
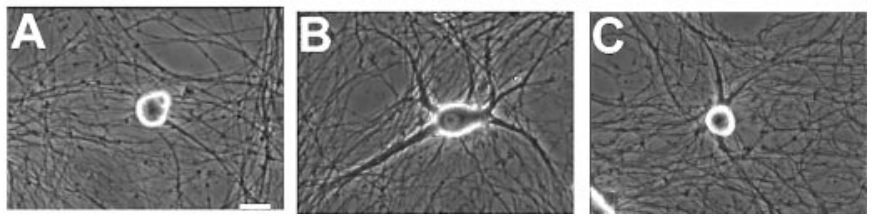

Figure 5. Effects of PACAP38 on axonal outgrowth of sympathetic neurons. $A$, Western blot for high molecular weight tau (a measure of axonal growth). Protein was extracted in $0.1 \%$ SDS and run on a $7.5 \%$ polyacrylamide gel; it was then transferred to a nitrocellulose membrane and processed for immunoblotting and chemiluminescent detection (as described in Materials and Methods). Tau protein was detected at 110 $\mathrm{kDa}$. $B$, Phase-contrast micrographs of neurons grown under control conditions $(A)$, in the presence of BMP-7 $(50 \mathrm{ng} / \mathrm{ml})(B)$, or BMP-7 and PACAP $(1 \mu \mathrm{M})(C)$. Differences in the axonal networks were not detected after any of the treatments. Scale bar, $20 \mu \mathrm{m}$.

$\mathrm{IC}_{50}$ of $\sim 1 \mu \mathrm{M}$. This concentration-effect profile of the peptides suggests the involvement of the $\mathrm{PAC}_{1}$ receptor, which exhibits greater affinity for PACAP38 or PACAP27 than for VIP (Lu et al., 1998).

Inhibitors of the PACAP/VIP receptor subtypes were used to further characterize the subtype(s) of receptor involved in the regulation of dendritic growth (Fig. 7). PACAP6-38 is a truncated form of PACAP38 that inhibits activation of the PAC ${ }_{1}$ and $\mathrm{VPAC}_{2}$ receptors (Robberecht et al., 1992; Beaudet et al., 2000; Liu et al., 2000). The peptide (Ac-Try $\left.{ }_{1}, \mathrm{D}-\mathrm{Phe}_{2}\right)-\mathrm{GRF}(1,29) \mathrm{NH}_{2}$ is an antagonist of the $\mathrm{VPAC}_{1}$ and $\mathrm{VPAC}_{2}$ receptors but not of $\mathrm{PAC}_{1}$ (Liu et al., 2000). In this experiment, PACAP27 was used as an agonist instead of PACAP38 because the former is more susceptible to the competitive blocking of PACAP6-38 at the $\mathrm{PAC}_{1}$ receptor (Beaudet et al., 2000; Vaudry et al., 2000b). Although inhibition of $\mathrm{VPAC}_{1}$ and $\mathrm{VPAC}_{2}$ receptor signaling did not alter the effect of PACAP27, inhibition of the $\mathrm{PAC}_{1}$ and $\mathrm{VPAC}_{2}$ receptors completely attenuated the inhibition of dendritic growth (Fig. 7). PACAP6-38 did not affect the morphology of neurons grown in the absence of BMP-7. These data suggest a primary role for the $\mathrm{PAC}_{1}$ receptor in the regulation of neuronal morphology.

\section{Inhibition of BMP-7-induced dendrite growth by PACAP38 and VIP involves the phosphorylation and nuclear translocation of phosphorylated CREB}

Activation of the $\mathrm{PAC}_{1}$ receptor stimulates adenylate cyclase and initiates the cAMP-signaling cascade in many cells (Ip et al., 1985; Deutsch and Sun, 1992; Lu et al., 1998; Kim et al., 2000). Therefore, we examined the phosphorylation and nuclear accumulation of CREB subsequent to treatment with PACAP38. Neurons were treated with BMP-7 in the presence or absence of

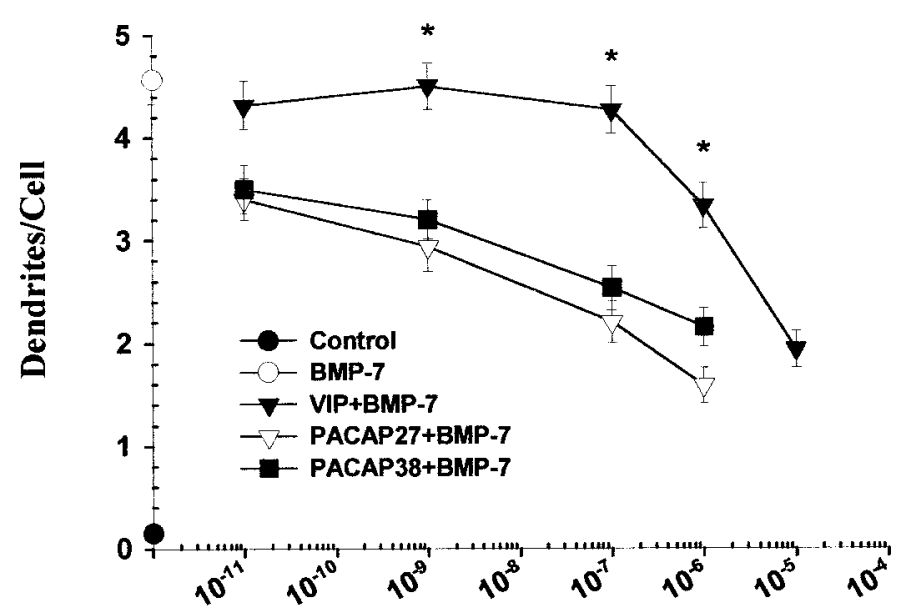

\section{Concentration (M)}

Figure 6. Comparison of concentration-effect relationships for PACAP27, PACAP38, and VIP. Beginning on the fifth day in vitro, sympathetic neurons were grown in control medium or medium with BMP-7, in the presence or absence of varying concentrations of PACAP27, PACAP38, or VIP. Cellular morphology was assessed by immunostaining using an antibody to MAP-2 on the 10th day in vitro. ${ }^{*} p<0.05$ versus BMP-7 in the presence of PACAP27 or PACAP38.

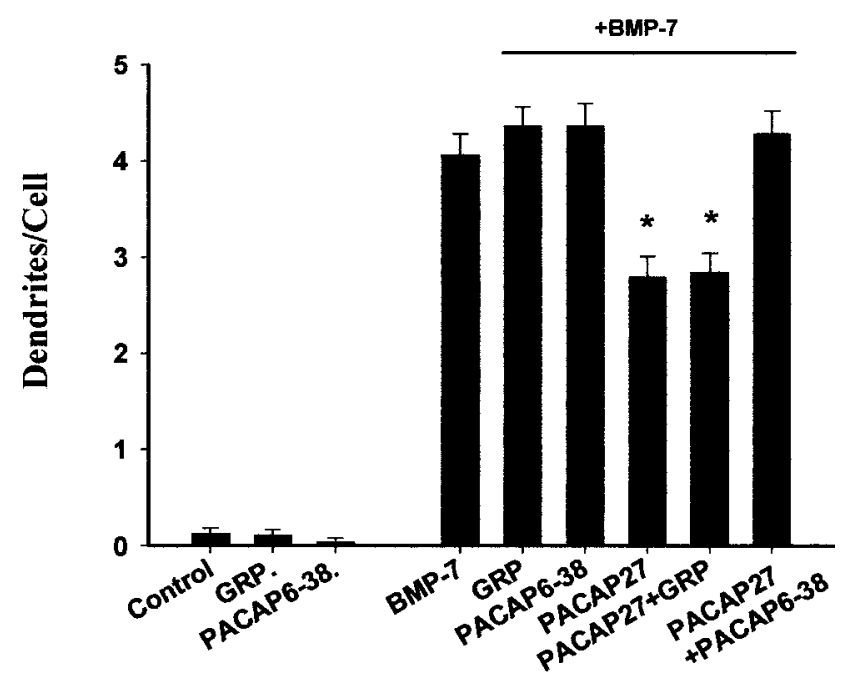

Figure 7. The inhibitory effects of PACAP and VIP on dendritic growth are mediated by the $\mathrm{PAC}_{1}$ receptor. Beginning on the fifth day in vitro, sympathetic neurons were continuously exposed to BMP-7 (50 ng/ml). At this time, some of the cells treated with BMP-7 were also pretreated for 15 min with an inhibitor of either the $\mathrm{VPAC}_{1}$ and $\mathrm{VPAC}_{2}$ receptors $(G R P, 1 \mu \mathrm{M})$ or of the $\mathrm{PAC}_{1}$ and $\mathrm{VPAC}_{2}$ receptors $(P A C A P 6-38,1 \mu \mathrm{M})$, after which the agonist PACAP27 was added for $5 \mathrm{~d}$. Cellular morphology was assessed by immunostaining using an antibody to MAP-2 on the 10th day in vitro. The concentration of PACAP27 was $1 \mathrm{nM}$, an amount approximately equivalent to its $\mathrm{ED}_{50}$. This concentration was used because PACAP6-38 was less effective as an antagonist with the maximum dose of PACAP27 ( $1 \mu \mathrm{M}$; data not shown). ${ }^{*} p<0.05$ versus BMP-7.

PACAP38 for $1 \mathrm{hr}$, after which cells were fixed and immunostained with a polyclonal antibody that recognizes phosphorylated forms of CREB (Fig. 8). In cells treated with BMP-7, there was faint diffuse staining of the cytoplasm with little or no nuclear reactivity (Fig. 8). In contrast, there was prominent nuclear staining for phosphorylated forms of CREB in cultures treated with PACAP38 and BMP-7, and the intensity of the reaction was 

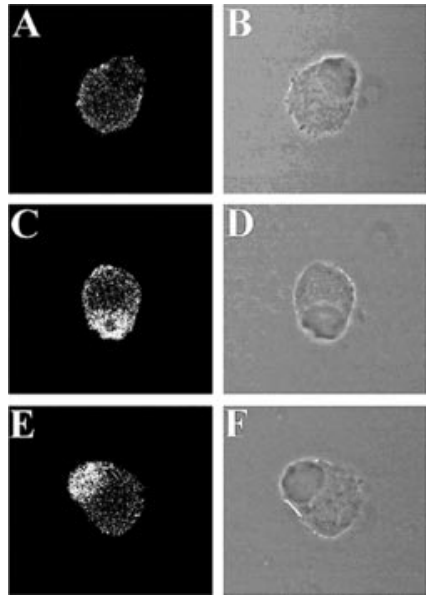

Figure 8. PACAP induces phosphorylation and nuclear translocation of CREB. Cells were treated with BMP-7 $(50 \mathrm{ng} / \mathrm{ml})$ alone $(A, B)$ or BMP-7 in the presence of forskolin $(10 \mu \mathrm{M})(C, D)$ or BMP-7 in the presence of PACAP38 $(1 \mu \mathrm{M})(E, F)$ for $1 \mathrm{hr}$ at $37^{\circ} \mathrm{C}$. Cells were subsequently immunostained with an antibody that reacts with a phosphorylated form (Ser 133) of CREB. Images were obtained using $1 \mu \mathrm{m}$ optical sections through cells with a Bio-Rad confocal microscope. Processes are not visible because we focused on a plane containing the nucleus. However, the neurons had been cultured for $5 \mathrm{~d}$ and were treated in a manner identical to those in other experiments. $A, C$, and $E$ are fluorescent micrographs showing the localization of phosphorylated CREB; $B, D$, and $F$ are the corresponding phase-contrast images.

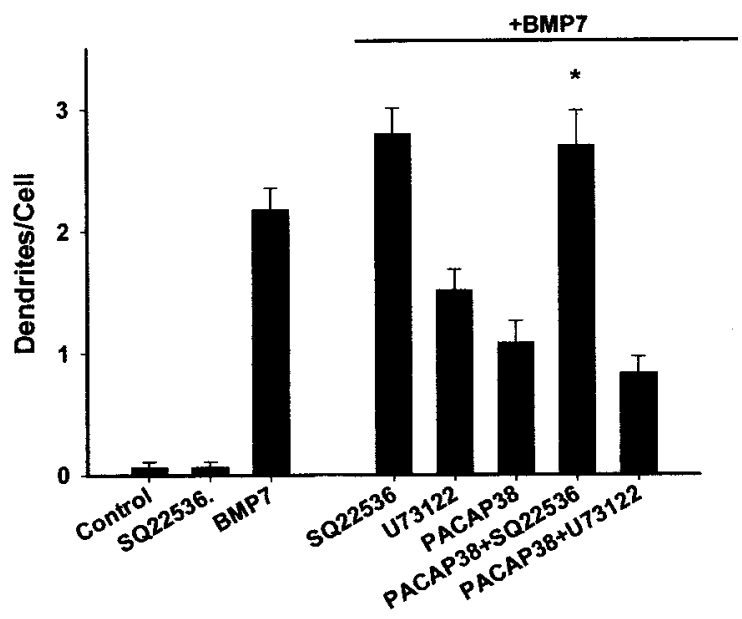

Figure 9. Inhibition of adenylate cyclase attenuates the inhibitory effect of PACAP38 on BMP-7-induced dendritic growth. Beginning on the fifth day in vitro, sympathetic neurons were exposed to BMP-7 $(50 \mathrm{ng} / \mathrm{ml})$, in the presence or absence of PACAP38 (1 $\mu \mathrm{M})$. In addition, some cultures were treated with the adenylate cyclase inhibitor SQ22536 $(400 \mu \mathrm{M})$ or the PLC inhibitor U73122 (2 $\mu \mathrm{M})$. Cellular morphology was assessed by immunostaining using an antibody to MAP-2 on the 10th day in vitro. ${ }^{*} p<0.05$ versus PACAP38 in the presence of BMP-7.

similar to that observed in cells treated with forskolin. These findings confirm that PACAP38 activates the cAMP/PKA signaling pathways in cultured sympathetic neurons (Lu et al., 1998; Braas and May, 1999).

\section{Inhibition of adenylate cyclase attenuates the inhibitory effect of PACAP38 on BMP-7-induced dendritic growth}

To identify which of the $\mathrm{PAC}_{1}$ receptor signaling pathways mediates the regulation of dendritic growth by PACAP38, cells were
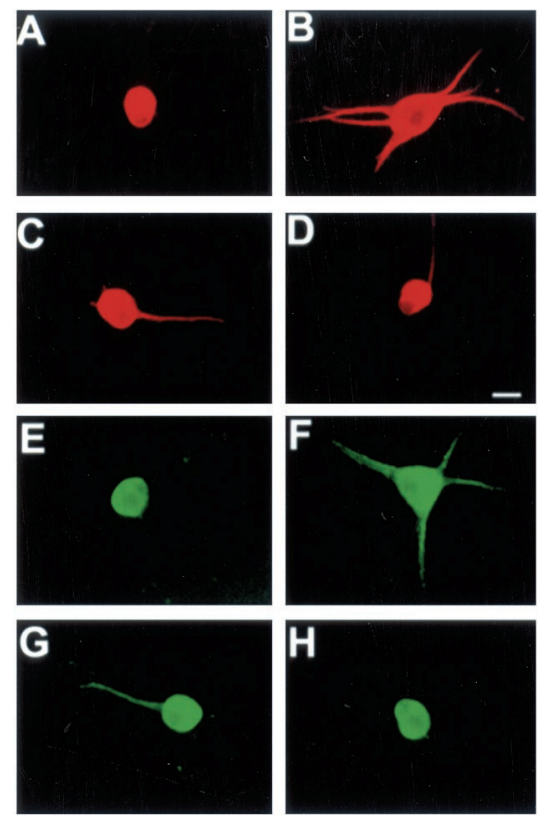

Figure 10. Elevation of cAMP inhibits BMP-7-induced dendritic growth in cultured sympathetic neurons. Sympathetic neurons were treated for $5 \mathrm{~d}$ with control medium $(A, E)$ or medium containing BMP-7 $(50 \mathrm{ng} / \mathrm{ml})$ $(B, F)$, forskolin $(10 \mu \mathrm{M})(D, H)$, or both BMP-7 and forskolin $(C, G)$. Two methods were used to assess alterations in dendritic growth. As in previous experiments, an antibody to MAP-2 was used to identify dendrites $(A-D)$; however, MAP-2 is a substrate for phosphorylation by PKA (Goto et al., 1985). To ensure that our results using the MAP-2 antibody were not affected by treatment-derived alterations in the phosphorylation state of MAP-2, the nucleic acid-binding dye YOYO-1 iodide (491/509) was also used. YOYO-1 iodide emits a fluorescent signal after binding to nucleic acids that are primarily localized to the somata and dendrites $(E-H)$. Analyses of the number of dendrites per cell for the two fluorescent stains were identical, suggesting that a change in the phosphorylation of MAP-2 by PKA does not affect results obtained by MAP-2 immunostaining.

treated for $3 \mathrm{~d}$ with BMP-7 in the presence or absence of either a phospholipase $\mathrm{C}$ inhibitor (U73122, $2 \mu \mathrm{M}$ ) or an inhibitor of adenylate cyclase (SQ22536, $400 \mu \mathrm{M})$. Treatment with U73122 did not affect the inhibition of BMP-7-induced dendritic growth by PACAP38. In contrast, cells treated with BMP-7 and PACAP38 in the presence of SQ22536 resembled cells grown in the presence of BMP-7 alone (Fig. 9). Thus, inhibition of adenylate cyclase completely attenuated the inhibitory effect of PACAP38 on BMP-7-induced dendritic growth. SQ22536 did not affect the morphology of neurons grown in the absence of BMP-7. These data indicate that activation of the cAMP signaling cascade is required for the regulation of dendritic growth by PACAP38 in sympathetic neurons.

\section{Agents that elevate cAMP inhibit BMP-7-induced dendritic growth}

To further explore the possibility that cAMP mediates the effects of PACAP38 and VIP on dendritic growth, we examined the effects of agents that modify intracellular concentrations of this cyclic nucleotide. Cells grown in control medium did not form dendrites, but treatment with BMP-7 induced dendritic growth (Fig. 10). Forskolin did not alter the morphology of cells grown in control medium, whereas neurons treated with BMP-7 in the presence of forskolin had $\sim 60 \%$ fewer dendrites than neurons treated with BMP-7 alone (Fig. 10). In addition, forskolin caused an $\sim 60 \%$ decrease in the overall size of the dendritic arbor (Fig. 


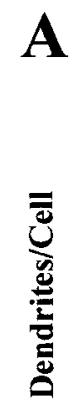

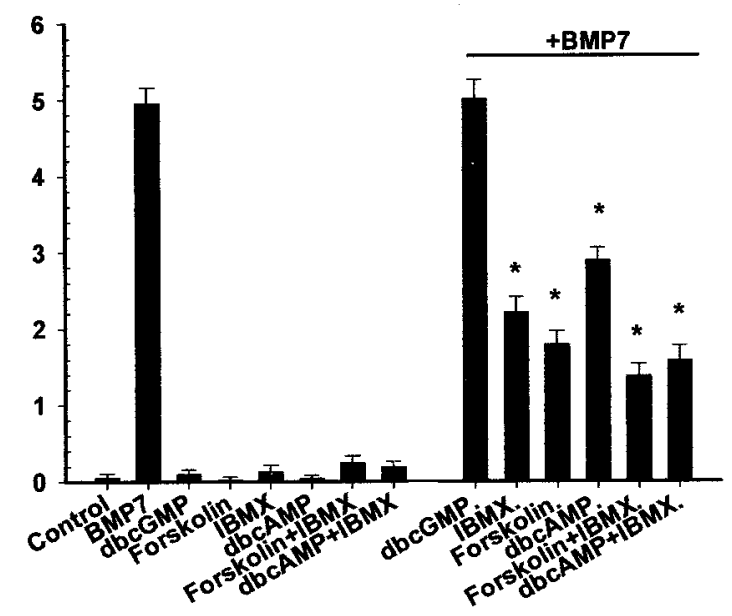

B

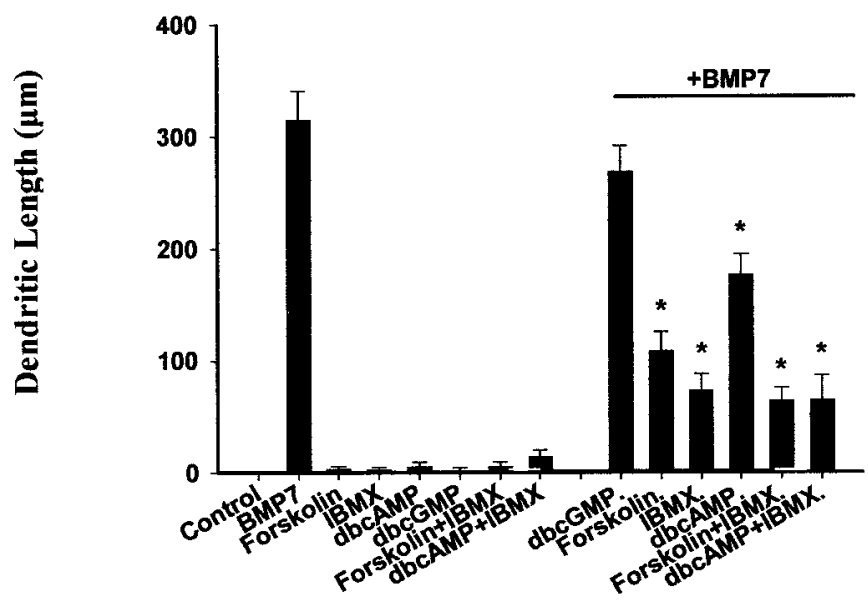

C

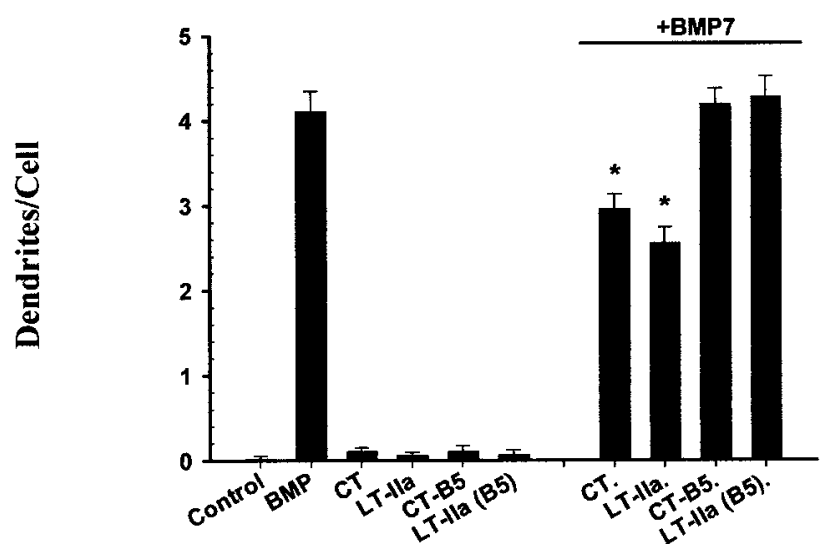

Figure 11. Agents that increase the intracellular concentration of cAMP inhibit BMP-7-induced dendritic growth. $A, B$, Sympathetic neurons were maintained for $5 \mathrm{~d}$ in the presence or absence of BMP-7 $(50 \mathrm{ng} / \mathrm{ml})$ with or without agents that alter cyclic nucleotide levels in a nonreceptormediated manner [Forskolin, $10 \mu \mathrm{M}$; dibutyryl cAMP (dbcAMP), $500 \mu \mathrm{M}$; $I B M X, 500 \mu \mathrm{M} ; d b c G M P, 500 \mu \mathrm{M}] . C$, In addition, some neurons were maintained for $5 \mathrm{~d}$ in control medium with or without BMP-7 $(50 \mathrm{ng} / \mathrm{ml})$, whereas some cultures were also exposed to CT (1 ng/ml) and LT-IIa (1 $\mathrm{ng} / \mathrm{ml})$. The B pentamer of both toxins, which binds to ganglioside

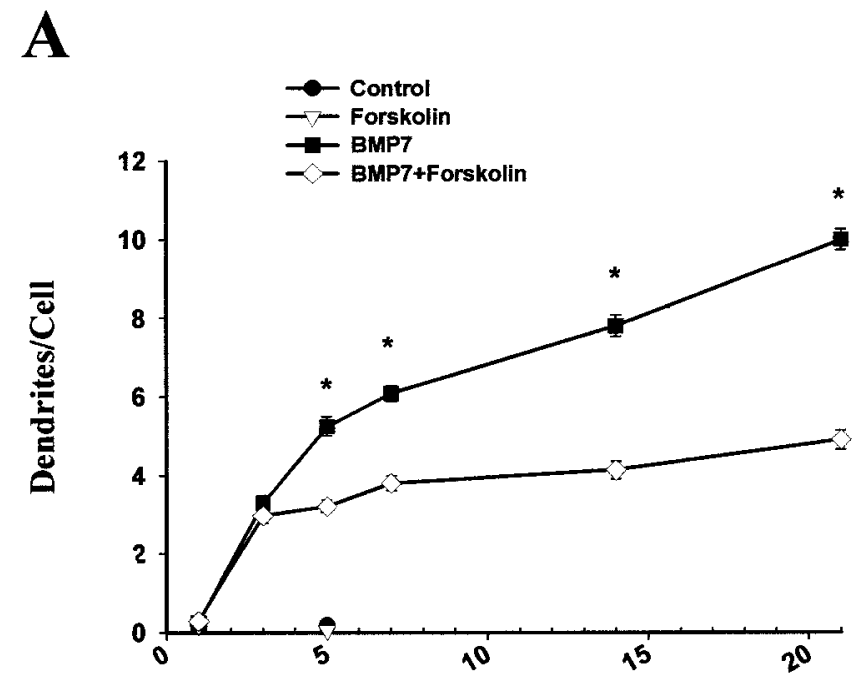

Days of Treatment

B

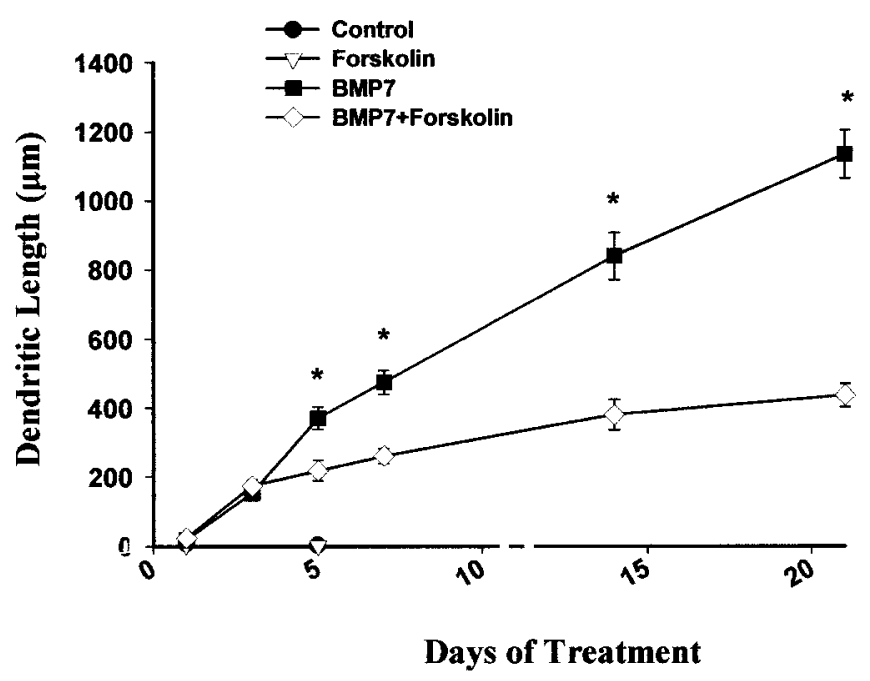

Figure 12. Long-term inhibition of BMP-7-induced dendritic growth by forskolin. Neurons were exposed to forskolin $(10 \mu \mathrm{M})$ in the presence or absence of BMP-7 (50 ng/ml), after which dendritic number $(A ; n=60)$ and total dendritic length $(B ; n=30)$ were determined by immunostaining with an antibody to MAP-2. Inhibition of BMP-7-induced dendritic growth by forskolin was statistically significant by the fifth day of culture, and the magnitude of the inhibition increased with time. ${ }^{*} p<0.05$ versus BMP-7.

11). The inhibitory effect of forskolin on dendritic extension was comparable to that exerted by PACAP38 $(\sim 50-60 \%)$, and it persisted for at least $21 \mathrm{~d}$ (Figs. 2, 12). As with PACAP38, forskolin treatment did not affect cell number or the expression of tau (data not shown).

receptors but does not activate adenylate cyclase, was used as a negative control. Dendritic number $(A, C ; n=60)$ and total length $(B ; n=30)$ were determined by immunostaining with an antibody to MAP-2. ${ }^{*} p<0.05$ versus BMP-7. 
PKA can phosphorylate MAP-2 (Goto et al., 1985); therefore, there was the possibility that forskolin could alter the binding of the antibody to MAP-2, a marker commonly used by our laboratory to identify these processes. To address this possibility, we used a second method for identifying dendrites. Several laboratories have reported that nucleic acid binding dyes selectively label dendrites (Knowles et al., 1996; Kiebler et al., 1999); therefore, YOYO-1 iodide (491/509), a fluorescent nucleic acid binding dye, was used to detect RNA localized to the soma and dendrites. Staining of cultures with this reagent yielded a pattern that was indistinguishable from that obtained with MAP-2 (Fig. 10). The magnitude of the forskolin-induced inhibition of dendritic growth was equivalent in cultures stained by these two methods.

Next, the morphological effects of several agents that elevate intracellular cAMP in a receptor-independent manner were examined (Fig. 11). The phosphodiesterase inhibitor 3-isobutyl-1methyl xanthine (IBMX) inhibited BMP-7-induced dendrite growth by $\sim 60 \%$. This was manifest as a decrease in both the number of dendrites and the total length of the dendritic arbor. Dibutyryl cAMP, in the presence or absence of IBMX, also reduced BMP-7-induced dendritic growth by 68 or $41 \%$, respectively, whereas dibutyryl cGMP had no effect. Thus, in addition to exogenous receptor-mediated regulators of cAMP, agents that activate this signaling system independently of receptor activation are also capable of altering neuronal morphology in sympathetic neurons.

Finally, to examine dendritic regulation by receptor-mediated cAMP elevating agents unrelated to PACAP38 or VIP, cultured neurons were treated with two potent activators of adenylate cyclase, cholera toxin (CT) and the enterotoxin LT-IIa (Fig. 11). These proteins induce irreversible ADP-ribosylation in target cells, leading to a sudden increase of cAMP production (Holmes et al., 1995). Both CT and LT-IIa inhibited BMP-7-induced dendritic growth in a manner comparable to that observed with PACAP or VIP. Similar to their respective holotoxins, the CT-B pentamer and the B pentamer of LT-IIa bind to GM1 ganglioside receptors located on eukaryotic cell surfaces (Holmes et al., 1995). Because the toxic A polypeptides are absent in these molecules, neither of the two B pentamers activate adenylate cyclase. To demonstrate that the effect on dendritic development resulted solely from toxin-dependent activation of adenylate cyclase, cultured neurons were also treated with CT-B pentamer and with the B pentamer of LT-IIa. Treatment of the cells with either B pentamer had no measurable effect on dendritic development (Fig. 11).

\section{DISCUSSION}

Growth factors regulate dendritic development (Lein et al., 1995, 1996; McAllister, 2001). In sympathetic neurons, the growth of these processes can be stimulated by NGF (Snider, 1988; Lein et al., 1995) or by several different members of the BMP superfamily (Lein et al., 1995; Guo et al., 1998). Moreover, the combination of these two types of growth factors is sufficient to allow cultured sympathetic neurons to develop dendritic arbors that are equivalent in size to those observed in vivo. During development, sympathetic neurons are dependent on NGF derived from peripheral targets for their survival and morphological development (Nja and Purves, 1978; Snider, 1988; Ruit et al., 1990; Lein et al., 1995). In addition, they are exposed to BMPs derived from local sources (Schneider et al., 1999), including glia in sympathetic ganglia (H. N. Beck, V. Chandrasekaran, P. J. Gallagher, Y. Lin, X. Guo, P. L. Kaplan, H. Tiedge, D. Higgins, and P. Lein, unpublished observations) and peripheral nerves (Schluesener et al., 1995). Target-derived BMPs may also be important because they have been found to regulate the development of dorsal root ganglia (Ai et al., 1999). We have used this model system to understand how neuropeptides interact with growth factors in the regulation of dendritic growth. In this regard, it is important to note that synaptic activity has been shown to modulate dendritic elongation and branching in many developing neural tissues (Mattson et al., 1988a,b; Cline, 2001). However, although previous studies focused on the involvement of rapidly acting transmitters, such as glutamate, in these processes, the role of neuropeptides has remained mostly unexplored.

In addition to acetylcholine, most preganglionic sympathetic axon terminals secrete neuropeptides from the VIP/PACAP/ secretin family, including VIP and PACAP38 (Baldwin et al., 1991; Beaudet et al., 1998). We found that PACAP38 and VIP potently inhibited BMP-7-induced dendritic growth in vitro. Thus, our data indicate that these neuropeptides can cause profound and long-lasting changes in cellular morphology. As specificity controls, we also examined the effects of peptides that are synthesized by preganglionic or postganglionic sympathetic neurons. However, neuropeptide $\mathrm{Y}$, leu-enkephalin, and substance $\mathrm{P}$ had no effect on dendritic growth, suggesting that the ability to regulate dendritic outgrowth is restricted to PACAP and VIP. In addition, although our laboratory has shown previously that acetylcholine by itself does not affect dendritic growth in sympathetic neurons, recent evidence indicates that acetylcholine may enhance the effects of PACAP or VIP in some tissues (Hamelink et al., 2002). Therefore, it will be of interest to see whether acetylcholine augments the inhibiting effects of PACAP and VIP on dendritic growth.

Members of the PACAP/VIP/secretin family of peptides have previously been found to acutely regulate membrane potential (Miura et al., 2001), nitric oxide synthesis (Khatun et al., 1999), and transmitter metabolism and release in sympathetic neurons (Ip and Zigmond, 2000; May et al., 2000). In addition, PACAPrelated peptides have long-term effects on these cells: they enhance the proliferation and survival of sympathetic neuroblasts (Nicot and DiCicco-Bloom, 2001) and also stimulate initial axon growth and peptide synthesis (Mohney and Zigmond, 1998, 1999; Zigmond, 2000). Thus, the inhibitory actions of PACAP and VIP on dendritic growth define a novel effect on perinatal sympathetic neurons, and they contrast with the generally stimulatory effects of these peptides on survival, differentiation, and neurite growth in embryonic sympathetic neuroblasts (Vaudry et al., 1998, 1999, 2000a,b; Nicot and DiCicco-Bloom, 2001). Thus, the response of sympathetic neurons to PACAP appears to evolve, changing from an initial stimulation of growth and survival in neuroblasts to an inhibition of dendritic growth and synapse formation in perinatal neurons. In this respect, it is important to note that apparently opposing activities have been observed with PACAP in other tissues. For example, although PACAP stimulates neurogenesis in sympathetic neuroblasts, it has the opposite effect on cerebral cortical precursors (Lu et al., 1998; Nicot and DiCicco-Bloom, 2001; Suh et al., 2001).

PACAP and VIP could negatively affect dendritic growth either by nonspecifically compromising cellular viability or by activating specific intracellular signaling pathways. However, treatment of sympathetic neurons with PACAP38 for $5 \mathrm{~d}$ did not affect cell survival, total cellular protein, or expression of tau, a cytoskeletal protein that is found primarily in axons. These data suggest that inhibition of BMP-7-induced dendritic growth by 
PACAP38 represents a specific morphogenic action on dendrites involving downstream signaling events.

Members of the PACAP/VIP/secretin family signal through three receptor subtypes: $\mathrm{PAC}_{1}, \mathrm{VPAC}_{1}$, and $\mathrm{VPAC}_{2}$. These receptors are expressed to varying degrees in different parts of the nervous system (for review, see Harmar et al., 1998). PAC $\mathrm{PA}_{1}$ has been identified as the predominant receptor subtype expressed by sympathetic neurons and has been implicated in the regulation of peptide secretion (May and Braas, 1995; Nogi et al., 1997; Lu et al., 1998; Beaudet et al., 2000). The $\mathrm{PAC}_{1}$ receptor is much more sensitive to PACAP than VIP, and consistent with its involvement in the regulation of dendritic growth, we found that PACAP was at least 1000-fold more potent than VIP as an inhibitor of processes outgrowth in sympathetic neurons. In addition, an antagonist that binds $\mathrm{PAC}_{1}$ and $\mathrm{VPAC}_{2}$ receptors abolished this effect, whereas an antagonist of the $\mathrm{VPAC}_{1}$ and $\mathrm{VPAC}_{2}$ receptors did not. Therefore, it is likely that the $\mathrm{PAC}_{1}$ receptor subtype is involved in the regulation of both peptide secretion and dendritic growth in sympathetic neurons.

In various tissues, binding of PACAP to $\mathrm{PAC}_{1}$ receptor can cause activation of adenylate cyclase, phospholipase C (PLC), and the MAP kinase signal transduction pathways (Vaudry et al., 2000b; Wascheck et al., 2000). In addition, PACAP and VIP increase levels of cAMP and inositol trisphosphate in sympathetic neurons (Ip et al., 1985; Pincus et al., 1990; DiCicco-Bloom et al., 1998; Mohney and Zigmond, 1998; Vaudry et al., 2000b). Our experiments reveal that PACAP induces the phosphorylation and nuclear translocation of CREB, a downstream element in the cAMP signal cascade (Schomerus et al., 1996), and that agents that increase intracellular levels of cAMP mimic the effects of PACAP and VIP on dendritic growth. These data strongly suggest that PACAP inhibits dendritic growth by a cAMP-dependent mechanism. This finding contrasts with the observations of May et al. (2000) who reported that PACAP38 modulated peptide release in sympathetic ganglia by a PLC/inositol trisphosphate signaling pathway rather than one involving cAMP. Thus, it would appear that there are at least two PACAP-sensitive signaling pathways that are active in sympathetic neurons and that each has a different consequence: PLC alters short-term neurotransmitter release, whereas PKA has long-term effects on cell shape.

PACAP and VIP are expressed in the preganglionic axons innervating the SCG and so are ideally positioned to participate in activity-dependent regulation of dendritic growth. One model for such modulation might be that during embryonic development, the dendritic arbor initially expands under the influence of the target-derived NGF and glial-derived BMPs, and the expansion continues until the dendrites receive adequate stimulation from preganglionic fibers, at which time their growth is stopped by exposure to VIP and PACAP. Consistent with this hypothesis, increased synapse formation during postnatal development (Black et al., 1971; Thoenen et al., 1972; Smolen, 1981; Wu and Black, 1988) correlates with the decline in the rate of dendritic growth (Voyvodic, 1989). In addition, PACAP and VIP could be involved in the remodeling of the dendritic arbor that occurs in adult animals (Purves and Hadley, 1985). At variance with this model is the report by Voyvodic (1989) that neonatal denervation does not produce an increase in the size of the dendritic arbor in the rat SCG. Experimental considerations may explain this apparent discrepancy with the proposed model. For instance, preganglionic sympathetic axons are typically activated during times of stress. However, laboratory animals are maintained under conditions that minimize stress, and so one would not expect activity-dependent effects in the sympathetic nervous system of animals housed under these conditions. This would be particularly relevant for peptidergic effects, because they tend to be most prominent at high rates of stimulation. However, it is likely that PACAP and VIP would be released at a much higher rate during exposure to stressors in the animals' native environment, outside of artificial laboratory conditions. Under these conditions, the peptides would be expected to have a greater role in the dendritic development of sympathetic neurons.

In summary, our data define a novel activity for neuropeptides found in preganglionic sympathetic fibers and demonstrate that they have the potential to function as morphogens. In addition, they suggest that PACAP and VIP may participate in a negative feedback loop that regulates dendritic growth in postganglionic neurons. PACAP and VIP may also regulate dendritic growth in response to neuronal injury. Glia from the SCG and peripheral nerves release the cytokine LIF after axotomy (Shadiack et al., 1993; Banner and Patterson, 1994; Sun and Zigmond, 1996; Sun et al., 1996), and LIF induces the expression of VIP in sympathetic neurons (Sun and Zigmond, 1996). Therefore, atrophy of the dendritic arbors subsequent to injury may be caused at least in part by increased expression and activity of VIP or PACAP, or both, in postganglionic sympathetic neurons, and this may constitute an additional component of the "cell body response" to injury (for review, see Zigmond, 1997).

\section{REFERENCES}

Ai X, Cappuzzello J, Hall AK (1999) Activin and bone morphogenetic proteins induce calcitonin gene-related peptide in embryonic sensory neurons in vitro. Mol Cell Neurosci 14:506-518.

Baldwin C, Sasek CA, Zigmond RE (1991) Evidence that some preganglionic sympathetic neurons in the rat contain vasoactive intestinal peptide-or peptide histidine isoleucine amide-like immunoreactivities. Neuroscience 40:175-184.

Banner LR, Patterson PH (1994) Major changes in the expression of the mRNAs for cholinergic differentiation factor/leukemia inhibitory factor and its receptor after injury to adult peripheral nerves and ganglia. Proc Natl Acad Sci USA 91:7109-7113.

Beaudet MM, Braas KM, May V (1998) Pituitary adenylate cyclase activating polypeptide (PACAP) expression in sympathetic preganglionic neurons to the superior cervical ganglion. J Neurobiol 36:325-336.

Beaudet MM, Parsons RL, Braas KM, May V (2000) Mechanisms mediating pituitary adenylate cyclase-activating polypeptide depolarization of rat sympathetic neurons. J Neurosci 20:7353-7361.

Black IB, Hendry IA, Iversen LL (1971) Regulation of the development of choline acetyl transferase in presynaptic nerves by post-synaptic neurones in mouse sympathetic ganglion. J Physiol (Lond) 216:41P-42P

Braas KM, May V (1999) Pituitary adenylate cyclase-activating polypeptides directly stimulate sympathetic neuron neuropeptide Y release through PAC(1) receptor isoform activation of specific intracellular signaling pathways. J Biol Chem 274:27702-27710.

Bruckenstein D, Johnson MI, Higgins D (1989) Age-dependent changes in the capacity of rat sympathetic neurons to form dendrites in tissue culture. Brain Res 46:21-32.

Cline HT (2001) Dendritic arbor and synaptogenesis. Curr Opin Neurobiol 11:118-126.

Deutsch PJ, Sun Y (1992) The 38-amino acid form of pituitary adenylate cyclase-activating peptide stimulates dual signaling cascades in PC12 cells and promotes neurite outgrowth. J Biol Chem 267:5108-5113.

DiCicco-Bloom E, Lu N, Pintar JE, Zhang J (1998) The PACAP ligand/ receptor system regulates cerebral cortical neurogenesis. Ann NY Acad Sci 865:274-289.

DiCicco-Bloom E, Deutsch PJ, Maltzman J, Zhang JW, Pintar JE, Zheng J, Friedman WF, Zhou XF, Zaremba T (2000) Autocrine expression and ontogenetic functions of the PACAP ligand/receptor system during sympathetic development. Dev Biol 219:197-213.

Goto S, Yamamoto H, Fukunaga K, Iwasa T, Matsukado Y, Miyamoto E (1985) Dephosphorylation of microtubule-associated protein 2, tau factor, and tubulin by calcineurin. J Neurochem 45:276-283.

Guo X, Metzler-Northrup J, Lein P, Rueger D, Higgins D (1997) Leukemia inhibitory factor and ciliary neurotrophic factor regulate dendritic growth in cultures of rat sympathetic neurons. Brain Res 104:101-110.

Guo X, Rueger D, Higgins D (1998) Osteogenic protein-1 and related 
bone morphogenetic proteins regulate dendritic growth and the expression of microtubule-associated protein-2 in rat sympathetic neurons. Neurosci Lett 245:131-134.

Guo X, Chandrasekaran V, Lein P, Kaplan P, Higgins D (1999) Leukemia inhibitory factor and ciliary neurotrophic factor cause dendritic retraction in cultured rat sympathetic neurons. $J$ Neurosci 19:2113-2121.

Hamelink C, Tjurmina O, Damadzic R, Young WS, Weihe E, Lee HW, Eiden LE (2002) Pituitary adenylate cyclase-activating polypeptide is a sympathoadrenal neurotransmitter involved in catecholamine regulation and glucohomeostasis. Proc Natl Acad Sci USA 99:461-466.

Harmar AJ, Arimura A, Gozes I, Journot L, Laburthe M, Pisegna JR, Rawlings SR, Robberecht P, Said SI, Sreedharan SP, Wank SA, Wascheck JA (1998) International Union of Pharmacology. XVIII. Nomenclature of receptors for vasoactive intestinal peptide and pituitary adenylate cyclase-activating polypeptide. Pharmacol Rev 50:265-270.

Hasbani MJ, Hyrc KL, Faddis BT, Romano C, Goldberg MP (1998) Distinct roles for sodium, chloride, and calcium in excitotoxic dendritic injury and recovery. Exp Neurol 154:241-258.

Higgins D, Lein P, Osterhout D, Johnson M (1991) Tissue culture of mammalian autonomic neurons. In: Culturing nerve cells (Banker $G$, Goslin K, eds), pp 177-205. Cambridge, MA: MIT.

Hirai H, Launey $\mathrm{T}$ (2000) The regulatory connection between the activity of granule cell NMDA receptors and dendritic differentiation of cerebellar Purkinje cells. J Neurosci 20:5217-5224.

Holmes RK, Jobling MG, Connell TD (1995) Cholera toxin and related enterotoxins of gram-negative bacteria. In: Handbook of natural toxins, Vol 8: Bacterial toxins and virulence factors in disease (Moss J, Iglewski B, Vaughan M, Tu AT, eds), pp 225-256. New York: Marcel Dekker.

Ip NY, Zigmond RE (2000) Synergistic effects of muscarinic agonists and secretin or vasoactive intestinal peptide on the regulation of tyrosine hydroxylase activity in sympathetic neurons. J Neurobiol 42:14-21.

Ip N Y, Baldwin C, Zigmond RE (1985) Regulation of the concentration of adenosine $3^{\prime}, 5^{\prime}$-cyclic monophosphate and the activity of tyrosine hydroxylase in the rat superior cervical ganglion by three neuropeptides of the secretin family. J Neurosci 5:1947-1954.

Isokawa M, Mello LE (1991) NMDA receptor-mediated excitability in dendritically deformed dentate granule cells in pilocarpine-treated rats. Neurosci Lett 129:69-73.

Johnson SM, Bywood PT (1998) Excitatory amino acid-induced degeneration of dendrites of catecholamine neurons in rat substantia nigra. Exp Neurol 151:229-236.

Khatun S, Kanayma N, Belayet HM, Sato E, Tokunaga N, Kobayashi T, Terao T (1999) The impact of vasoactive peptides on nitric oxide production in cultured sympathetic neurons. Neuroscience 93:605-609.

Kiebler MA, Hemraj I, Verkade P, Kohrmann M, Fortes P, Marion RM, Ortin J, Dotti CG (1999) The mammalian staufen protein localizes to the somatodendritic domain of cultured hippocampal neurons: implications for its involvement in mRNA transport. J Neurosci 19:288-297.

Kim WK, Kan Y, Ganea D, Hart RP, Gozes I, Jonakait GM (2000) Vasoactive intestinal peptide and pituitary adenylyl cyclase-activating polypeptide inhibit tumor necrosis factor- $\alpha$ production via a cAMPdependent pathway. J Neurosci 20:3622-3630.

Knowles RB, Sabry JH, Martone ME, Deerinck TJ, Ellisman MH, Bassell GJ, Kosik KS (1996) Translocation of RNA granules in living neurons. J Neurosci 16:7812-7820.

Kosik KS, Caceres A (1991) Tau protein and the establishment of an axonal morphology. J Cell Sci [Suppl] 15:69-74

Laemmli UK (1970) Cleavage of structural proteins during the assembly of the head of bacteriophage T4. Nature 227:680-685.

Landis SC (1994) Development of sympathetic neurons: neurotransmitter plasticity and differentiation factors. Prog Brain Res 100:19-23.

Lein PJ, Higgins D (1991) Protein synthesis is required for the initiation of dendritic growth in embryonic rat sympathetic neurons in vitro. Brain Res Brain Res 60:187-196.

Lein P, Johnson M, Guo X, Rueger D, Higgins D (1995) Osteogenic protein-1 induces dendritic growth in rat sympathetic neurons. Neuron 15:597-605.

Lein P, Guo X, Hedges AM, Rueger D, Johnson M, Higgins D (1996) The effects of extracellular matrix and osteogenic protein-1 on the morphological differentiation of rat sympathetic neurons. Int $\mathrm{J} \mathrm{Dev}$ Neurosci 14:203-215.

Lima L, Obregon F, Matus P (1998) Taurine, glutamate and GABA modulate the outgrowth from goldfish retinal explants and its concentrations are affected by the crush of the optic nerve. Amino Acids 15:195-209.

Liu DM, Cuevas J, Adams DJ (2000) VIP and PACAP potentiation of nicotinic ACh-evoked currents in rat parasympathetic neurons is mediated by G-protein activation. Eur J Neurosci 12:2243-2251.

Lu N, Zhou R, DiCicco-Bloom E (1998) Opposing mitogenic regulation by PACAP in sympathetic and cerebral cortical precursors correlates with differential expression of PACAP receptor $\left(\mathrm{PAC}_{1}-\mathrm{R}\right)$ isoforms. J Neurosci Res 53:651-662.
Mattson MP, Dou P, Kater SB (1988a) Outgrowth-regulating actions of glutamate in isolated hippocampal pyramidal neurons. J Neurosci 8:2087-100.

Mattson MP, Guthrie PB, Kater SB (1988b) Intracellular messengers in the generation and degeneration of hippocampal neuroarchitecture. J Neurosci Res 21:447-464.

May V, Braas KM (1995) Pituitary adenylate cyclase-activating polypeptide (PACAP) regulation of sympathetic neuron neuropeptide $\mathrm{Y}$ and catecholamine expression. J Neurochem 65:978-987.

May V, Beaudet MM, Parsons RL, Hardwick JC, Gauthier EA, Durda JP, Braas KM (1998) Mechanisms of pituitary adenylate cyclase activating polypeptide (PACAP)-induced depolarization of sympathetic superior cervical ganglion (SCG) neurons. Ann NY Acad Sci 865:164-175.

May V, Beaudet MM, Parsons RL, Braas KM (2000) PACAP modulates rat sympathetic neuron depolarization through IP3. Ann NY Acad Sci 921:186-194.

McAllister AK (2001) Neurotrophins and neuronal differentiation in the central nervous system. Cell Mol Life Sci 58:1054-1060.

Miura A, Kawatani M, de Groat WC (2001) Effects of pituitary adenylate cyclase activating polypeptide on lumbosacral preganglionic neurons in the neonatal rat spinal cord. Brain Res 895:223-232.

Mohney RP, Zigmond RE (1998) Vasoactive intestinal peptide enhances its own expression in sympathetic neurons after injury. J Neurosci 18:5285-5293.

Mohney RP, Zigmond RE (1999) Galanin expression is decreased by cAMP-elevating agents in cultured sympathetic ganglia. NeuroReport 10:1221-1224.

Nicot A, DiCicco-Bloom E (2001) Regulation of neuroblast mitosis is determined by PACAP receptor isoform expression. Proc Natl Acad Sci USA 98:4758-4763.

Nja A, Purves D (1978) The effects of nerve growth factor and its antiserum on synapses in the cervical superior ganglion of the guinea pig. J Physiol (Lond) 277:55-75.

Nogi H, Hashimoto H, Hagihara N, Shimada S, Yamamoto K, Matsuda'Tohyama M, Baba A (1997) Distribution of mRNAs for pituitary adenylate cyclase-activating polypeptide (PACAP), PACAP receptor, vasoactive intestinal polypeptide (VIP), and VIP receptors in the rat superior cervical ganglion. Neurosci Lett 227:37-40.

Paglini G, Peris L, Mascotti F, Quiroga S, Caceres A (2000) Tau protein function in axonal formation. Neurochem Res 25:37-42.

Pfau D, Westphal S, Bossanyi PV, Dietzmann K (1995) Abnormal dendritic maturation of neurons under the influence of a Tilorone analogue. Exp Toxicol Pathol 47:367-374.

Pincus DW, DiCicco-Bloom E, Black IB (1990) Vasoactive intestinal peptide regulation of neuroblast mitosis and survival: role of cAMP. Brain Res 514:355-357

Pisegna JR, Wank SA (1993) Cloning and characterization of the signal transduction of four splice variants of the human pituitary adenylate cyclase activating polypeptide receptor. Evidence for dual coupling to adenylate cyclase and phospholipase C. J Biol Chem 271:17267-17274

Purves D, Hadley RD (1985) Changes in the dendritic branching of adult mammalian neurones revealed by repeated imaging in situ. Nature 315:404-406.

Purves D, Snider WD, Voyvodic JT (1988) Trophic regulation of nerve cell morphology and innervation in the autonomic nervous system. Nature 336:123-128.

Robberecht P, Gourlet P, De Neef P, Woussen-Colle MC, VandermeersPiret MC, Vandermeers A, Christophe J (1992) Structural requirements for the occupancy of pituitary adenylate-cyclase-activatingpeptide (PACAP) receptors and adenylate cyclase activation in human neuroblastoma NB-OK-1 cell membranes. Discovery of PACAP(6-38) as a potent antagonist. Eur J Biochem 207:239-246.

Ruit KG, Osborne PA, Schmidt RE, Johnson Jr EM, Snider WD (1990) Nerve growth factor regulates sympathetic ganglion cell morphology and survival in the adult mouse. J Neurosci 10:2412-2419.

Sasek CA, Baldwin C, Zigmond RE (1991) Distribution of vasoactive intestinal peptide- and peptide histidine isoleucine amide-like immunoreactive neurons and fibers in the thoracic spinal cord of the rat. Brain Res 567:159-164.

Schluesener HJ, Meyermann R, Jung S (1995) Immunolocalization of vgr (BMP-6, DVR-6), a TGF-beta related cytokine, to Schwann cells of the rat peripheral nervous system: expression patterns are not modulated by autoimmune disease. Glia 13:75-78.

Schneider C, Wicht H, Enderich J, Wegner M, Rohrer H (1999) Bone morphogenetic proteins are required in vivo for the generation of sympathetic neurons. Neuron 24:861-870.

Schomerus C, Maronde E, Laedtke E, Korf HW (1996) Vasoactive intestinal peptide (VIP) and pituitary adenylate cyclase-activating polypeptide (PACAP) induce phosphorylation of the transcription factor CREB in subpopulations of rat pinealocyctes: immunocytochemical and immunochemical evidence. Cell Tissue Res 286:305-313.

Shadiack AM, Hart RP, Carlson CD, Jonakait GM (1993) Interleukin-1 induces substance $\mathrm{P}$ in sympathetic ganglia through the induction of leukemia inhibitory factor (LIF). J Neurosci 13:2601-2609. 
Smolen AJ (1981) Postnatal development of ganglionic neurons in the absence of preganglionic input: morphological observations on synapse formation. Brain Res 227:49-58.

Snider WD (1988) Nerve growth factor enhances dendritic arborization of sympathetic ganglion cells in developing mammals. J Neurosci $8: 2628-2634$

Spencer GE, Klumperman J, Syed NI (1998) Neurotransmitters and neurodevelopment. Role of dopamine in neurite outgrowth, target selection and specific synapse formation. Perspect Dev Neurobiol 5:451-467.

Spengler D, Waeber C, Pantaloni C, Holsboer F, Bockaert J, Seeburg PH, Journot L (1993) Differential signal transduction by five splice variants of the PACAP receptor. Nature 365:170-175.

Suh J, Lu N, Nicot A, Tatsuno I, DiCicco-Bloom E (2001) PACAP is an anti-mitogenic signal in developing cerebral cortex. Nat Neurosci 4:123-124.

Sun Y, Zigmond RE (1996) Involvement of leukemia inhibitory factor in the increases in galanin and vasoactive intestinal peptide mRNA and the decreases in neuropeptide $\mathrm{Y}$ and tyrosine hydroxylase mRNA in sympathetic neurons after axotomy. J Neurochem 67:1751-1760.

Sun Y, Rao MS, Zigmond RE, Landis SC (1994) Regulation of vasoactive intestinal peptide expression in sympathetic neurons in culture and after axotomy: the role of cholinergic differentiation factor/leukemia inhibitory factor. J Neurobiol 25:415-430.

Sun YS, Landis SC, Zigmond R (1996) Signals triggering the induction of leukemia inhibitory factor in sympathetic superior cervical ganglia and their nerve trunks after axonal injury. Mol Cell Neurosci $7: 152-163$.

Taleghany N, Oblinger MM (1992) Regional distribution and biochemical characteristics of high molecular weight tau in the nervous system. J Neurosci Res 33:257-265.

Thoenen H, Kettler R, Saner A (1972) Time course of the development of enzymes involved in the synthesis of norepinephrine in the superior cervical ganglion of the rat from birth to adult life. Brain Res 40:459-468.
Vaudry D, Basille M, Anouar Y, Fournier A, Vaudry H, Gonzalez BJ (1998) The neurotrophic activity of PACAP on rat cerebellar granule cells is associated with activation of the protein kinase A pathway and c-fos gene transcription. Ann NY Acad Sci 865:92-99.

Vaudry D, Gonzalez BJ, Basille M, Fournier A, Vaudry H (1999) Neurotrophic activity of pituitary adneylate cylcase-activating polypeptide on rat cerebellar cortex during development. Proc Natl Acad Sci USA 96:9415-9420.

Vaudry D, Gonzalez BJ, Basille M, Pamantung TF, Fontaine M, Fournier A, Vaudry H (2000a) The neuroprotective effect of pituitary adenylate cyclase-activating polypeptide on cerebellar granule cells is mediated through inhibition of the CED3-related cysteine protease caspase-3/ CPP32. Proc Natl Acad Sci USA 97:13390-13395.

Vaudry D, Yon L, Fournier A, Vaudry H (2000b) Pituitary adenylate cyclase-activating polypeptide and its receptors: from structure to function. Pharmacol Rev 52:269-324.

Voyvodic JT (1989) Peripheral target regulation of dendritic geometry in the rat superior cervical ganglion. J Neurosci 9:1997-2010.

Wascheck JA, DiCicco-Bloom EM, Lelievre V, Zhou X, Hu Z (2000) PACAP action in nervous system development, regeneration, and neuroblastoma cell proliferation. Ann NY Acad Sci 921:129-136.

Wilson MT, Kisaalita WS, Keith CH (2000) Glutamate-induced changes in the pattern of hippocampal dendritic outgrowth: a role for calciumdependent pathways and the microtubule cytoskeleton. J Neurobiol 43:159-172.

Wu K, Black IB (1988) Transsynaptic impulse activity regulates postsynaptic density molecules in developing and adult rat superior cervical ganglion. Proc Natl Acad Sci USA 85:6207-6210.

Zigmond RE (1997) LIF, NGF, and the cell body response to axotomy. Neuroscientist 3:176-185.

Zigmond RE (2000) Neuropeptide action in sympathetic ganglia. Evidence for distinct functions in intact and axotomized ganglia. Ann NY Acad Sci 921:103-108. 